\title{
Comparative assessment of methods for metagenomic DNA isolation from soils of different crop growing fields
}

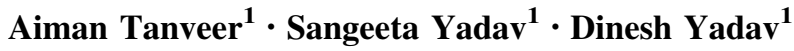

Received: 13 August 2016/Accepted: 4 October 2016/Published online: 12 October 2016

(C) The Author(s) 2016. This article is published with open access at Springerlink.com

\begin{abstract}
The isolation of good quality metagenomic DNA from diverse soil, in appreciable amount, is a prerequisite for metagenomics. The availability of commercial kits for isolation of genomic DNAs from soil has drastically expedited the application of metagenomics approach for identifying novel sources of industrially important enzymes. The quantitative and qualitative assessment of metagenomic DNA isolated using either the manual method or the kit-based method should be performed prior to its use in downstream applications. The metagenomic DNA isolated from six different soil samples, using three methods, were analyzed in terms of yield, quality and downstream application as template for PCR amplification. The yield of DNA was approximately 3.52, 7.35, and $232.42 \mu \mathrm{g}$ of DNA per gram of soil sample for the kitbased method, kit-modified method, and manual method, respectively. The manual method seems to be promising based on better yield and lesser humic acid content than the other two methods. The maximum yield was obtained in the soil collected from teak forest with all the three methods, indicating maximum microbial content and diversity. Furthermore, in terms of its suitability as template DNA for PCR amplification using 16S RNA primer, all methods are equally well. Thus, comparative assessment of three methods revealed suitability of manual method based on DNA yield and humic acid content, which could be important for many downstream applications like library preparations during metageomics approach.
\end{abstract}

Dinesh Yadav

dinesh_yad@rediffmail.com

1 Department of Biotechnology, D.D.U Gorakhpur University, Gorakhpur, UP 273 009, India
Keywords Metagenomics · Genomic DNA · Soil · Quantitative · Qualitative

\section{Introduction}

Soil comprises of complex biological ecosystem containing wide plethora of microbial entities. The microbial population is known to be a vast reservoir of numerous biomolecules, biocatalysts, antibiotics, and antibiotic resistance genes (Daniel 2005; Riesenfeld et al. 2004; Simon and Daniel 2011). The immense biological treasure stored in the ecosystem either in soil, water, and air needs to be explored. Researchers have attempted to explore this rich ecosystem by culturing the microbial strains under laboratory conditions but this account for less $1 \%$ of the total microbial diversity (Handelsman 2004). In order to assess the remaining microbial diversity, 'metagenomics' is the only alternative and has been extensively reviewed over the years (Fernandez-Arrojo et al. 2010; Schmeisser et al. 2007; Steele et al. 2009; Uchiyama and Miyazaki 2009). Metagenomic involves analysis of DNA from diverse soil, marine, and airborne habitats. DNA extracted from the microbial communities is cloned in the hosts which can be easily cultured in laboratory conditions (Handelsman 2004). The library is then screened for the desired biomolecules.

The isolation of metagenomic DNA from soil is an important consideration and needs standardization. Since soil is rich in organic matter like humic acid and other inhibitory substances, which hinder downstream applications like PCR amplification and cloning, several protocols have been reported in literature (Berthelet et al. 1996; Gutiérrez-Lucas et al. 2014; Nair et al. 2014; Picard et al. 1992). 
The study is primarily focused on the assessment of methods for the isolation of metagenomic DNA from different soil samples, for identifying novel sources of industrially important enzymes of pectinases group, especially pectin lyases (Yadav et al. 2009). Using metagenomic approach, an attempt has been made to access the quantity and quality of soil genomic DNA isolated from different sources using different methods. In this study, a comparative assessment of genomic DNA isolated by the kit-based and manual methods from six different soil samples consisting of different crops is discussed.

\section{Materials and methods}

\section{Soil samples}

A total of six soil samples, five representing soils from agricultural field with mustard, broad bean, pea, sugarcane, and wheat crops, and one soil sample representing the teak dominated Kushmi forest located in Gorakhpur, Uttar Pradesh, India (Latitude $26^{\circ} 13^{\prime} \mathrm{N}$ and $27^{\circ} 29^{\prime} \mathrm{N}$ and Longitude $83^{\circ} 05^{\prime} \mathrm{E}$ and $83^{\circ} 56^{\prime} \mathrm{E}$ ), were used in this study. The greater part of the district falls in the eastern sector of the Indo-Gangetic plain containing older alluvium (Bangar) and new alluvium (Khadar) soil types.

\section{Genomic DNA extraction}

Metagenomic DNA was extracted by three different methods, namely, HiPurA soil DNA isolation kit (Himedia), modified HiPurA soil DNA isolation kit, and manual method (Nair et al. 2014) using soil samples from six different locations.

\section{Method 1: HiPurA soil DNA isolation kit (Himedia)}

The metagenomic DNA was extracted as per manufacturer's instructions. Both mechanical actions, i.e., bead beating, heating and chemical lysis is involved in the process. The sample is subjected to cycle of intensive vortexing, heating and vortexing. The inhibitor removal solution is added for removing impurities like humic acid and other PCR inhibitors. The supernatant after addition of the binding solution was loaded on the spin column. The column was centrifuged to bind the DNA to spin column and the column was washed with wash buffer provided in the kit. The DNA is finally eluted with the elution buffer and could be stored at $-20{ }^{\circ} \mathrm{C}$ freezer.

\section{Method 2: Modified HiPurA soil DNA isolation kit (Himedia)}

A slight modification of the protocol mentioned in HiPurA soil DNA isolation kit (Himedia), namely, addition of
RNase A $(1 \mu \mathrm{g} / \mathrm{ml})$ along with the inhibitor removal solution and incubating it at $37{ }^{\circ} \mathrm{C}$ for $1 \mathrm{~h}$. Second, along with the wash buffers provided in the kit, additional washes were performed with $70 \%$ ethanol twice. The sample was eluted in the elution buffer preheated at $65^{\circ} \mathrm{C}$.

\section{Method 3: Manual method}

This method has been reported by Volossiouk et al. (1995) and Nair et al. (2014). In this method, the soil was ground to fine powder in aseptic conditions and suspended in $0.4 \% \mathrm{w} / \mathrm{v}$ solution of skimmed milk. The solution was vortexed well and centrifuged at $12,000 \mathrm{~g}$ for $10 \mathrm{~min}$. To the supernatant, $2 \mathrm{ml}$ of SDS extraction buffer (0.3\% SDS in $0.14 \mathrm{M} \mathrm{NaCl}, 50 \mathrm{mM}$ sodium acetate, $\mathrm{pH}$ 5.1) was added and mixed well by vortexing. Equal volume of tris saturated phenol was added and vortexed again for $2 \mathrm{~min}$. Tube was centrifuged at $12,000 \mathrm{~g}$ for $10 \mathrm{~min}$ and supernatant was collected. DNA was precipitated with equal volume of ice-cold isopropanol at $-20{ }^{\circ} \mathrm{C}$ for $1 \mathrm{~h}$. The DNA pellet was recovered by centrifugation at $12,000 \mathrm{~g}$ for 10 min. Pellet was washed twice with $70 \%$ ethanol and air dried. Pellet was dissolves in sterile water and stored at $-20{ }^{\circ} \mathrm{C}$ deep freezer.

\section{Quantitative and qualitative assessment of metagenomic DNA}

The isolated metagenomic DNA was analyzed by standard agarose gel electrophoresis loading equal quantities of DNA on the agarose gel along with $\lambda$ HindIII digest marker (Maniatis et al. 1982). Purity and concentration of DNA were estimated by Nanodrop. The yield of extracted DNA was determined by measuring absorbance at wavelength of $260 \mathrm{~nm}$. The purity of corresponding DNA samples was determined by the calculating $A_{260} / A_{280}$ (DNA/protein) and $A_{260} / A_{230}$ (DNA/humic acid) ratios to determine protein and humic acid contamination, respectively. $A_{260} / A_{280}$ ratio of less than 1.8 indicates protein contamination (Maniatis et al. 1982), while $A_{260} / A_{230}$ value less than 2 indicates humic acid contamination (Ning et al. 2009). Furthermore, the quality of genomic DNA isolated from soil samples were assessed for PCR amplification using 16S rRNA gene specific primer. The primer sequences are, forward primer: AGAGTTTGATCCTGGCTCAG; reverse primer: TACGGYTACCGTGTTACGACTTK.

\section{Statistical analysis}

The isolation of metagenomic DNA using different methods from different soil samples were repeated thrice and values of absorbance and the absorbance ratios according calculated for mean and standard deviations. Microsoft 
excel was used for all the statistical calculations and graph preparation.

\section{Results and discussion}

The key step in the metagenomic workflow is the isolation of high-quality metagenomic DNA with good yield. This study was focused on the selection of optimal method for extraction of metagenomic DNAs from various crop growing fields of north-eastern Tarai Gorakhpur region of Uttar Pradesh, India. Isolation of good quality DNA for application in other downstream applications is a challenging task. One of the hurdles in isolation of high-quality DNA is the co-purification of other contaminating molecules present in the soil like humic acid, heavy metals, and some pigments. Among these, humic acid creates the major menace as it is present in all the soil types playing major reservoir of organic carbon in soil. Irrespective of the soil source, around $0.7-3.3 \mathrm{mg} / \mathrm{ml}$ of humic acid contaminant, may be present in any crude DNA preparation (Tebbe and Vahjen 1993). Major reason for its co-purification is its three-dimensional structure with functional reactive groups through which it binds during the purification process (Stevenson 1976). Moreover, it shares the same properties as the DNA molecule, making it more difficult to separate from the metagenomic DNA during the isolation steps.

There are several reports of metagenomic DNA isolation from different soil samples. Classical methods comprises of both mechanical and chemical means for shearing the cells. Mechanical shearing in the form of bead beating (Dong et al. 2006), or heating at $65{ }^{\circ} \mathrm{C}$ (Zhou et al. 1996) or subjecting the cells to alternate cycle of freeze and thaw conditions (Tsai and Olson 1991) has been attempted. Various buffer combinations containing detergents are used for lysis and subsequent purification step in genomic DNA isolation. However, currently, commercial DNA isolation kits are becoming popular for isolation of good quality metagenomic DNA in lesser time. Irrespective of the commercial sources, the kits basically work on the principle of adsorption and desorption of DNA on the silica column in the presence of chaotropic salts. The isolated metagenomic DNAis routinely used for estimation of functional diversity, taxonomic classification, and community structure studies (Jimenez et al. 2012; Jung et al. 2016; Uroz et al. 2013).

The metagenomic DNA isolated from six different soil samples, using three methods, were analyzed in terms of yield, quality and downstream application as template for PCR amplification. The yield of genomic DNA was comparatively higher for method 3, i.e., manual method (Nair et al. 2014) as compared to HiMedia kit-based method 1 and modified kit method 2 (Fig. 1). The selection of this manual method (Ogram et al. 1987) was based on reports of being the best method assessed during comparative analysis of five reported methods for soil DNA extraction (Nair et al. 2014).

The maximum yield was obtained in the soil collected from teak forest with all the three methods. This also indicates maximum microbial content and their diversity in the Teak forest. The quantity of DNA amounted to around $3.52,7.35$, and $232.42 \mu \mathrm{g}$ of DNA per gram of soil sample for the kit-based method, kit-modified method, and manual method, respectively. The yield obtained by the manual method was much better than some other reported methods. Approximately $1.29 \mu \mathrm{g}$ of DNA was extracted by the method reported by Zhou et al. (1996). Yeates et al. (1998) have used mechanical means for the isolation of the metagenomic DNA. They have obtained 3.42 and $1.47 \mu \mathrm{g}$ of DNA per gram of soil using glass beads and sonicator, respectively. A very good yield of $746.46 \mu \mathrm{g}$ of DNA per gram of soil has been reported by Tsai and Olson (1991).

Irrespective of the methods used, the genomic DNA was of good quality with discrete bands, as visualized on agarose gel (Fig. 1). The qualities of DNA isolated by different methods from six different soil samples were further assessed for the presence of protein and humic acid contaminants. Manual method seems to be more efficient in the effective removal of humic acid contaminants (Fig. 2a)

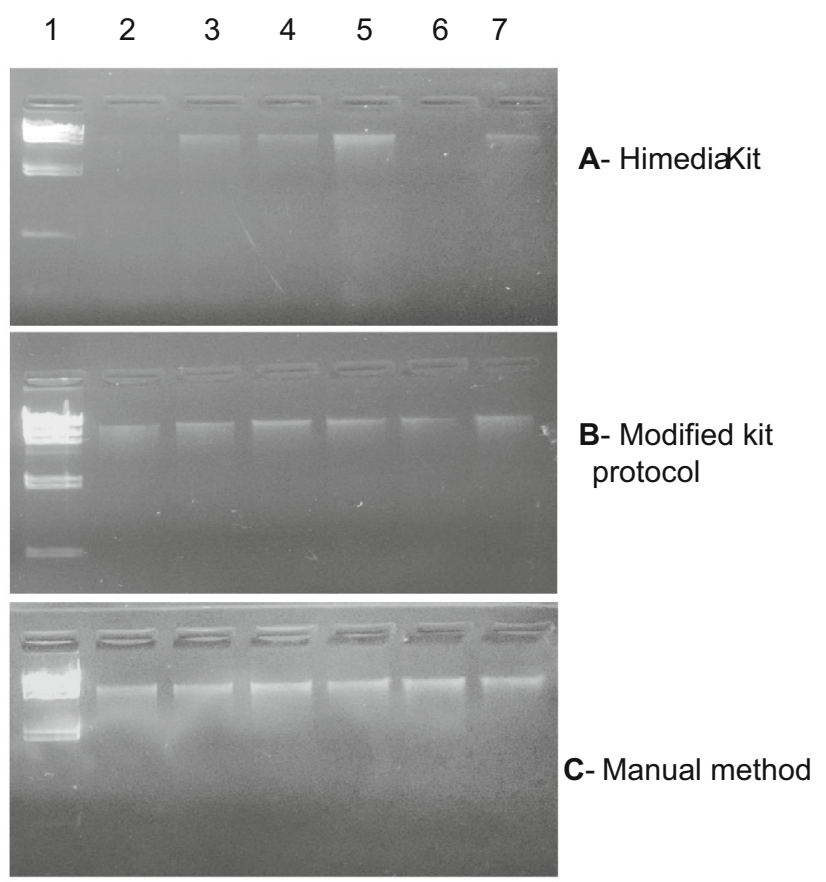

Fig. $10.8 \%$ agarose gel showing genomic DNA, isolated from different soil samples using, a Himedia kit, b modified kit protocol, and $\mathbf{c}$ manual method. Lane 1 lambda-HindIII marker DNA, lane 2 mustard field, lane 3 teak forest, lane 4 broad bean, lane 5 pea field, lane 6 sugarcane field, and lane 7 wheat field 
as compared to other methods tested, based on values of $A_{260} / A_{230}$ calculated for each samples. The $A_{260} / A_{230}$ ratio of less than two indicates the presence of humic acid contamination (Ning et al. 2009). For better performance of the kit-based methods, the humic acid and other possible contaminant in the isolated DNA can be minimized by

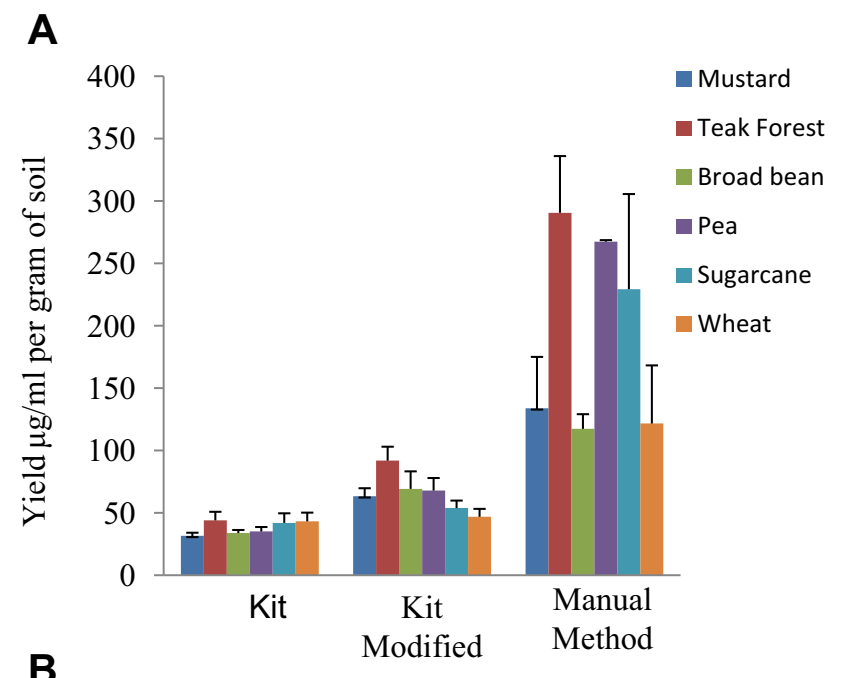

B

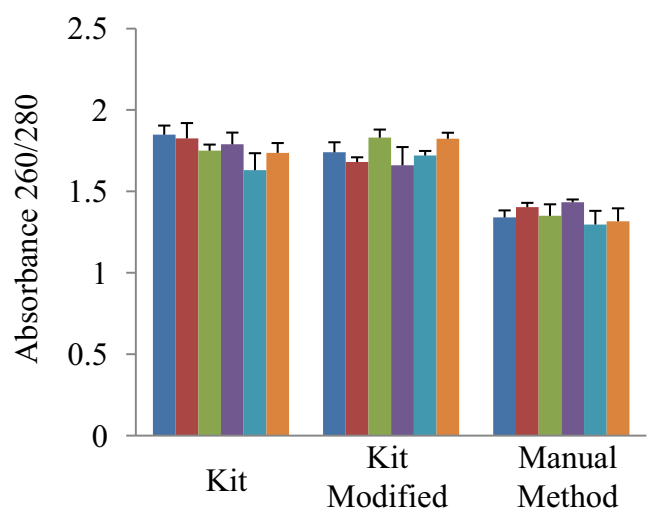

C

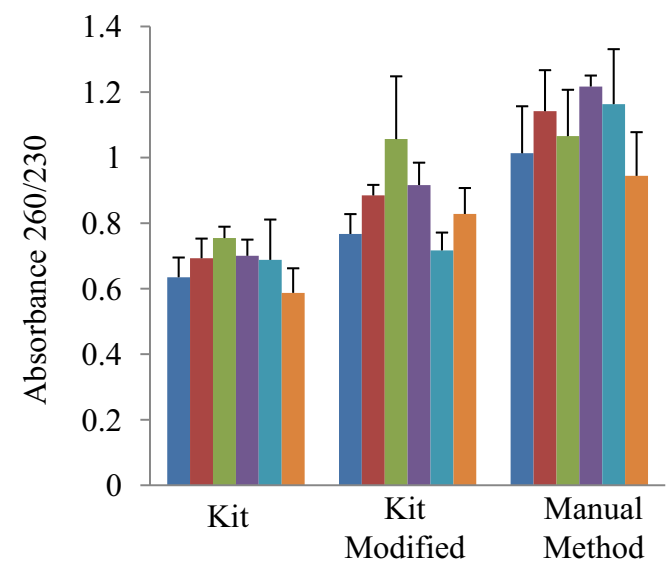

Fig. 2 Comparative assessment of metagenomic DNA isolation methods for a yield, b protein contamination (Absorbance 260/280), and c humic acid contamination (Absorbance 260/230) additional washing steps by $70 \%$ ethanol (Fig. 2c). Furthermore, the RNA co-purified by the purification procedure can be removed by RNase treatment. The protein contamination as analyzed by determining $A_{260} / A_{280}$ was also assessed for isolated metagenomic DNAs using different methods. The manual method (Method 3) seems to have more protein contamination than kit-based methods (Fig. 2b).

Quality of the isolated metagenomic DNAs was further analyzed for downstream application mainly as template for PCR amplification using 16S rRNA primer. In general, a high-quality DNA free from contaminants is a prerequisite for PCR amplification. Humic acid acts as an inhibitor in PCR by binding to the DNA molecule hindering the amplification of the DNA molecule (Opel et al. 2010); hence, the template soil DNA should be free of humic acid contamination. The PCR amplification using soil metagenomic DNAs with $16 \mathrm{~S}$ rRNA primer resulted in expected size amplicons of $1.5-\mathrm{kb}$ size (Fig. 3) irrespective of the isolation methods used, indicating the acceptability of all the methods tested.

Thus, in this study, it is quite evident that the manual method gives comparatively better yield along with lesser humic acid contaminants, as compared with the other two methods. Although all the methods tested are satisfactory as evident from the PCR amplification, the yield of metagenomic DNA is quite variable and this could be an

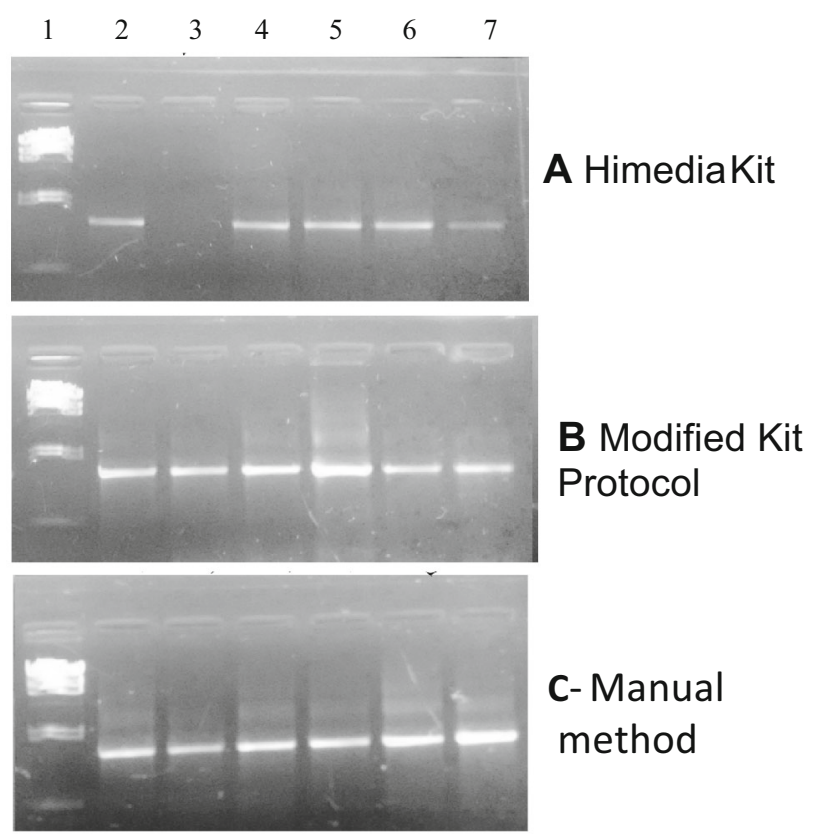

Fig. $31.5 \%$ agarose gel showing PCR amplification of 16S rRNA using genomic DNA isolated from different soil samples as template a Himedia kit, $\mathbf{b}$ modified kit protocol, and $\mathbf{c}$ manual method. Lane 1 lambda-HindIII marker DNA, lane 2 mustard field, lane 3 teak forest, lane 4 broad bean, lane 5 pea field, lane 6 sugarcane field, and lane 7 wheat field 
important consideration for many downstream applications like library preparations during metageomics approach. Furthermore, these methods are equally suitable for different soil types used in this study.

Currently, there are no reports about the metagenomics studies of soil from the crop growing fields of Gorakhpur district of Uttar Pradesh, India. Since it is an agriculturally dominant region, metagenomic studies need to be carried out to look into the rich microbial diversity present in the soil. This is probably for the first time metagenomic studies have been performed from different soils of this region and quality checked by PCR amplification of 16S rRNA gene. The reproducibility of protocol for metagenomic DNA isolation is an important consideration and needs to properly investigated prior to applying metagenomic approaches for isolating novel sources of enzymes.

Acknowledgments The financial support in the form of UGC-Dr. D. S. Kothari Post-Doctoral fellowship to A. Tanveer, SERB Young Scientist Fellowship (SB/FT/LS-430/2012) to S. Yadav is thankfully acknowledged. The authors acknowledge the infrastructural support from the Head, Department of Biotechnology, D.D.U. Gorakhpur University, Gorakhpur.

Open Access This article is distributed under the terms of the Creative Commons Attribution 4.0 International License (http:// creativecommons.org/licenses/by/4.0/), which permits unrestricted use, distribution, and reproduction in any medium, provided you give appropriate credit to the original author(s) and the source, provide a link to the Creative Commons license, and indicate if changes were made.

\section{References}

Berthelet M, Whyte LG, Greer CW (1996) Rapid, direct extraction of DNA from soils for PCR analysis using polyvinylpolypyrrolidone spin columns. FEMS Microbiol Lett 138:17-22

Daniel R (2005) The metagenomics of soil. Nature Rev Microbiol 3:470-478. doi:10.1038/nrmicro1160

Dong DX, Yan A, Liu HM, Zhang XH, Xu YQ (2006) Removal of humic substances from soil DNA using aluminium sulfate. J Microbiol Methods 66:217-222

Fernandez-Arrojo L, Guazzaroni ME, Lopez-Cortes N, Beloqui A, Ferrer M (2010) Metagenomic era for biocatalyst identification. Curr Opin Biotechnol 21:725-733. doi:10.1016/j.copbio.2010. 09.006

Gutiérrez-Lucas LR, Montor-Antonio JJ, Cortés-López NG, del Moral S (2014) Strategies for the extraction, purification and amplification of metagenomic DNA from soil growing sugarcane. Adv Biol Chem 4:281-289

Handelsman J (2004) Metagenomics: application of genomics to uncultured microorganisms. Microbiol Mol Biol Rev 68:669-685. doi:10.1128/MMBR.68.4.669-685.2004

Jimenez DJ et al (2012) Structural and functional insights from the metagenome of an acidic hot spring microbial planktonic community in the Colombian Andes. PLoS One 7:e52069. doi:10.1371/journal.pone.0052069

Jung J, Philippot L, Park W (2016) Metagenomic and functional analyses of the consequences of reduction of bacterial diversity on soil functions and bioremediation in diesel-contaminated microcosms. Sci Rep 6:23012. doi:10.1038/srep23012

Maniatis T, Fritsch EF, Sambrook J (1982) Molecular cloning: a laboratory manual. Cold Spring Harbor Laboratory, Cold Spring Harbor

Nair HP, Vincent H, Bhat SG (2014) Evaluation of five in situ lysis protocols for PCR amenable metagenomic DNA from mangrove soils. Biotech Rep 4:134-138

Ning J, Liebich J, Kastner M, Zhou J, Schaffer A, Burauel P (2009) Different influences of DNA purity indices and quantity on PCRbased DGGE and functional gene microarray in soil microbial community study. Appl Microbiol Biotechnol 82:983-993. doi:10.1007/s00253-009-1912-0

Ogram A, Sayler GS, Barkay TJ (1987) DNA extraction and purification from sediments. J Microbiol Methods 7:57-66

Opel KL, Chung D, McCord BR (2010) A study of PCR inhibition mechanisms using real time PCR. J Forensic Sci 55:25-33. doi:10.1111/j.1556-4029.2009.01245.x

Picard C, Ponsonnet C, Paget E, Nesme X, Simonet P (1992) Detection and enumeration of bacteria in soil by direct DNA extraction and polymerase chain reaction. Appl Environ Microbiol 58:2717-2722

Riesenfeld CS, Goodman RM, Handelsman J (2004) Uncultured soil bacteria are a reservoir of new antibiotic resistance genes. Environ Microbiol 6:981-989. doi:10.1111/j.1462-2920.2004. 00664. $\mathrm{x}$

Schmeisser C, Steele H, Streit WR (2007) Metagenomics, biotechnology with non-culturable microbes. Appl Microbiol Biotechnol 75:955-962. doi:10.1007/s00253-007-0945-5

Simon C, Daniel R (2011) Metagenomic analyses: past and future trends. Appl Environ Microbiol 77:1153-1161. doi:10.1128/ AEM.02345-10

Steele HL, Jaeger KE, Daniel R, Streit WR (2009) Advances in recovery of novel biocatalysts from metagenomes. J Mol Microbiol Biotechnol 16:25-37. doi:10.1159/000142892

Stevenson FJ (1976) Stability constants of $\mathrm{Cu}, \mathrm{Pb}$ and $\mathrm{Cd}$ complexes with humic acids. Soil Sci Am J 40:665-672

Tebbe CC, Vahjen W (1993) Interference of humic acids and DNA extracted directly from soil in detection and transformation of recombinant DNA from bacteria and a yeast. Appl Environ Microbiol 59:2657-2665

Tsai YL, Olson BH (1991) Rapid method for direct extraction of DNA from soil and sediments. Appl Environ Microbiol 57:1070-1074

Uchiyama T, Miyazaki K (2009) Functional metagenomics for enzyme discovery: challenges to efficient screening. Curr Opin Biotechnol 20:616-622. doi:10.1016/j.copbio.2009.09.010

Uroz S, Ioannidis P, Lengelle J, Cebron A, Morin E, Buee M, Martin F (2013) Functional assays and metagenomic analyses reveals differences between the microbial communities inhabiting the soil horizons of a Norway spruce plantation. PLoS One 8:e55929. doi:10.1371/journal.pone.0055929

Volossiouk T, Robb EJ, Nazar RN (1995) Direct DNA extraction for PCR-mediated assays of soil organisms. Appl Environ Microbiol 61:3972-3976

Yadav S, Yadav PK, Yadav D, Yadav KD (2009) Purification and characterization of pectin lyase produced by Aspergillus terricola and its application in retting of natural fibers. Appl Biochem Biotechnol 159:270-283. doi:10.1007/s12010-008-8471-1

Yeates C, Gillings MR, Davison AD, Altavilla N, Veal DA (1998) Methods for microbial DNA extraction from soil for PCR amplification. Biol Proced Online 1:40-47. doi:10.1251/bpo6

Zhou J, Bruns MA, Tiedje JM (1996) DNA recovery from soils of diverse composition. Appl Environ Microbiol 62:316-322 